\title{
PENERAPAN PENDEKATAN SAINTIFIK PADA PENDIDIKAN ANAK USIA DINI
}

\author{
Maria Fatima Mardina Angkur \\ Jurusan PG-PAUD, Sekolah Tinggi Keguruan dan Ilmu Pendidikan STKIP Santu Paulus Ruteng, Nusa \\ Tenggara Timur, Indonesia. \\ E-mail: mariafatimamardinaangkur@gmail.com, Telp: 085341731984
}

\begin{abstract}
Abstrak
Kurikulum 2013 di PAUD sangatlah penting untuk kita kaji. Termasuk ketika ada kebijakan untuk menerapkan di semua jenjang PAUD meskipun bekal para pelaku pendidikan di Pendidikan Anak Usia Dini (PAUD) masih sangat sedikit. Salah satu karakteristik Kurikulum 2013 adalah adanya pendekatan saintifik dalam proses pembelajarannya. Kurikulum 2013 Pendidikan Anak Usia Dini mengamanatkan bahwa pembelajaran di PAUD menggunakan pendekatan saintifik dalam pemberian rangsangan pendidikan. Pendekatan saintifik adalah salah satu pendekatan dalam membangun cara berpikir agar anak memiliki kemampuan menalar yang diperoleh melalui proses mengamati sampai pada mengomunikasikan hasil pikirnya. Guru dipandang perlu untuk menerapkan pendekatan saintifik dalam pembelajaran di kelas. Yang menjadi masalah adalah bagaimana cara menerapkan pendekatan saintifik dalam pembelajaran? Oleh karena itu, peneliti merasa tertarik untuk menulis tentang penerapan pendekatan saintifik pada pendidikan anak usia dini.
\end{abstract}

Kata kunci: Pendekatan Saintifik, Pembelajaran, PAUD.

\section{THE APPLICATION OF SCIENTIFIC APPROACHES IN EARLY CHILDHOOD EDUCATION}

\begin{abstract}
The 2013 curriculum in early childhood education is very important for us to examine. Including when there is a policy to implement in all early childhood Education level, although provision of the principals of education in early childhood education is still very little. One characteristic of the curriculum is the scientific approach to 2013 in process analytical study. 2013 curriculum, early childhood education mandates that learning in early childhood education using a scientific approach in the awarding of educational stimuli. A scientific approach is one approach in developing a way of thinking so that children have the ability menalar acquired through the process observed until on communicating results of he thought. The teacher is seen necessary to apply a scientific approach in the learning in the classroom. The problem was how to apply scientific approach in learning? Therefore, researchers feel interested to write about the application of the scientific approach in early childhood education.
\end{abstract}

Keywords: Scientific Approach, Learning, Early Childhood Education

\section{PENDAHULUAN}

Kurikulum 2013 di PAUD sangatlah penting untuk kita kaji. Termasuk ketika ada kebijakan untuk menerapkan di semua jenjang PAUD meskipun bekal para pelaku pendidikan di Pendidikan Anak Usia Dini (PAUD) masih sangat sedikit. Salah satu karakteristik Kurikulum 2013 adalah adanya pendekatan saintifik dalam proses pembelajarannya. Kurikulum 2013 Pendidikan Anak Usia Dini mengamanatkan bahwa pembelajaran di
PAUD menggunakan pendekatan saintifik dalam pemberian rangsangan pendidikan.

Pendekatan saintifik adalah proses pembelajaran yang dirancang sedemikian rupa agar peserta didik membangun kompetensi sikap, pengetahuan, dan keterampilan melalui tahapan mengamati, menanya, mengumpulkan informasi, menalar dan mengkomunikasikan. Pendekatan saintifik tidak diartikan sebagai belajar sain tetapi menggunakan proses saintis dalam kegiatan belajar. 
Pendekatan saintifik adalah salah satu pendekatan dalam membangun cara berpikir agar anak memiliki kemampuan menalar yang diperoleh melalui proses mengamati sampai pada mengomunikasikan hasil pikirnya.

Hal ini didasarkan pada pemikiran Piaget yang mengatakan bahwa "Anak belajar dengan cara membangun pengetahuannya sendiri melalui pengalaman yang diperolehnya". Vygotsky berpendapat bahwa "Lingkungan, termasuk anak lain atau orang dewasa dan media sangat membantu anak dalam belajar untuk memperkaya pengalaman anak. Untuk itu, kurikulum 2013 PAUD mengusung cara belajar anak agar memiliki kompetensi sikap, pengetahuan dan keterampilan yang merupakan proses hasil penyelidikan (investigasi) anak terhadap lingkungannya.

Penanaman sikap dibangun melalui pembiasaan (habituasi) dan keteladanan (modeling). Pengembangan pengetahuan dan keterampilan dapat dilakukan melalui pendekatan saintifik (untuk penanaman sikap akan dipandu dengan pedoman tersendiri).

Pendekatan saintifik mengembangkan kemampuan berpikir anak. Pendekatan saintifik digunakan pada saat anak terlibat dalam kegiatan main (termasuk saat kegiatan pembelajaran sains), maupun kegiatan lainnya, misalnya main peran, main balok, main keaksaraan, atau melakukan kegiatan seni.

Sebagian besar lembaga Pendidikan Anak Usia Dini di Manggarai telah menerapkan Kurikulum 2013. Dengan kata lain, sekolah juga telah menerapkan pendekatan saintifik. Meskipun demikian masih ditemukan informasi bahwa guru anak usia dini masih mengalami kebingungan dalam menerapkan kurikulum 2013.

\section{PENDIDIKAN ANAK USIA DINI}

Berdasarkan Undang-Undang Nomor 23 Tahun 2003 tentang Sistem Pendidikan Nasional, pendidikan anak usia dini adalah suatu upaya pembinaan yang ditujukan kepada anak sejak lahir sampai usia enam tahun yang dilakukan melalui pemberian rangsangan pendidikan untuk membantu pertumbuhan dan perkembangan jasmani dan rohani agar anak memiliki kesiapan dalam dalam memasuki pendidikan lebih lanjut.

Usia dini merupakan masa emas perkembangan. Pada masa itu terjadi lonjakan luar biasa pada perkembangan anak yang tidak terjadi pada periode berikutnya. Para ahli menyebutnya usia emas perkembangan (golden age). Untuk melejitkan potensi perkembangan tersebut, setiap anak membutuhkan asupan gizi seimbang, perlindungan kesehatan, asuhan penuh kasih sayang, dan rangsangan pendidikan yang sesuai dengan tahap perkembangan dan kemampuan masingmasing anak. Pemberian rangsangan pendidikan dapat dilakukan sejak lahir, bahkan sejak masih dalam kandungan. Rangsangan pendidikan ini hendaknya dilakukan secara bertahap, berulang, konsisten, dan tuntas sehingga memiliki daya ubah (manfaat) bagi anak. (Helmawati, 2015).

\section{PRINSIP-PRINSIP PRAKTIS DALAM PEMBELAJARAN /KEGIATAN PAUD}

Salah satu pilar konsep dasar PAUD adalah prinsip-prinsip pelaksanaan pembelajaran. Berikut ini akan dijabarkan 10 prinsip pelaksanaan pembelajaran PAUD. (Suyadi dan Ulfah, 2012).

1) Belajar Melalui Bermain Anak di bawah usia 6 tahun berada pada masa bermain.

Pemberian rangsangan Pendidikan dengan cara yang tepat melalui bermain, dapat memberikan pembelajaran yang bermakna pada anak.

2) Berorientasi Pada Perkembangan Anak Guru harus mampu mengembangkan semua aspek perkembangan sesuai dengan usia anak.

Perkembangan anak tergantung pada kematangan anak. Kematangan anak dipengaruhi oleh status gizi, kesehatan, pengasuhan, Pendidikan, dan faktor bawaan. Perkembangan anak bersifat individu. Anak yang usianya sama bisa jadi perkembangannya berbeda. Guru perlu memberikan kegiatan dan dukungan yang sesuai dengan tahapan perkembangan anak secara perseorangan walaupun kegiatannya dilakukan di dalam kelompok. Untuk itulah pentingnya Guru memahami tahapan perkembangan anak.

3) Berorientasi Pada Kebutuhan Anak.

Secara Menyeluruh Guru harus mampu memberi rangsangan Pendidikan atau stimulasi sesuai dengan kebutuhan anak, termasuk anakanak yang mempunyai kebutuhan khusus. Untuk dapat hidup secara sehat dan cerdas membutuhkan: a. Kenyamanan; b. Pengasuhan, Gizi; c. Pendidikan; dan d. Perlindungan. Program layanan PAUD harus memenuhi kebutuhan tersebut. Penyelenggara PAUD harus bekerjasama dengan layanan kesehatan, gizi, 
kesejahteraan sosial, hukum, dan orang tua. Dengan kata lain layanan PAUD Holistik Integratif menjadi keharusan termasuk untuk anak berkebutuhan khusus.

4) Berpusat Pada Anak

Anak diberi kesempatan untuk mencari, menemukan, menentukan pilihan, mengemukakan pendapat, dan aktif melakukan serta mengalami sendiri Anak sebagai pusat pembelajaran, artinya: a. Kegiatan pembelajaran direncanakan dan dilaksanakan untuk mengembangkan seluruh potensi fisik dan psikhis anak; b. Kegiatan pembelajaran dilaksanakan dengan cara yang menyenangkan sesuai dengan cara berpikir dan perkembangan kognitif anak; c. Pembelajaran PAUD berorientasi pada anak, bukan pemenuhan keinginan lembaga/guru/orang tua.

5) Pembelajaran Aktif

Guru harus mampu menciptakan kegiatan-kegiatan yang menarik dan membangkitkan rasa ingin tahu anak, memotivasi anak untuk berfikir kritis, dan kreatif. Pembelajar aktif berarti anak belajar, melakukan atas dasar idenya bukan hanya mengikuti instruksi atau arahan guru. Pembelajaran aktif tidak hanya aktif anggota tubuhnya, tetapi yang penting juga aktif proses berpikirnya.

6) Berorientasi Pada Pengembangan Karakter

Pemberian rangsangan Pendidikan dan pembelajaran diarahkan untuk mengembangkan nilai-nilai karakter. Pengembangan nilainilai karakter dilakukan secara terpadu baik melalui pembiasaan dan keteladanan baik yang bersifat spontan maupun terprogram. Nilai-nilai karakter yang termuat dalam kompetensi dasar sikap meliputi: a. Menerima ajaran agama yang dianutnya; $b$. Menghargai diri sendiri, orang lain dan lingkungan; c. Memiliki perilaku hidup sehat; d. rasa ingin tahu; e. kreatif; f. estetis; g. percaya diri; h. disiplin; i. sabar; j. mandiri; k. peduli; 1 . toleran; m. menyesuaikan diri; n. bertanggung jawab; o. jujur; p. rendah hati; dan q. santun dalam berinteraksi

7) Berorientasi Pada Pengembangan Kecakapan Hidup

Pemberian rangsangan Pendidikan dan pembelajaran diarahkan untuk mengembangkan kecakapan hidup anak. Kecakapan hidup yang dimaksud adalah kemampuan untuk menolong diri sendiri, sehingga anak tidak tergantung secara fisik maupun pikiran kepada orang lain. Pengembangan kecakapan hidup dilakukan secara terpadu baik melalui pembiasaan, keteladanan, maupun kegiatan terprogram.

8) Lingkungan Kondusif

Lingkungan pembelajaran diciptakan sedemikian rupa agar menarik, menyenangkan, aman, dan nyaman bagi anak. Penataan ruang diatur agar anak dapat berinteraksi dengan Guru, pengasuh, dan anak lain. Lingkungan yang kondusif mampu mendorong munculnya proses pemikiran ilmiah. Lingkungan yang kondusif atau yang mendukung mencakup suasana yang baik, waktu yang cukup, dan penataan yang tepat. Waktu yang cukup maksudnya waktu cukup untuk bermain, cukup untuk beristirahat, dan cukup untuk bersosialisasi. Suasana lingkungan yang mendukung anak belajar: a. Memberikan perlindungan dan kenyamanan saat anak bermain dengan bahan dan alat sesuai ide anak; b. Memberi kebebasan untuk anak melakukan eksplorasi dan eksperimentasinya; c. Memberi kesempatan anak untuk memberikan penjelasan tentang cara kerja dan hasil yang dibuatnya.; d. Menyediakan berbagai alat dan bahan yang dapat mendukung cara anak bermain; e. Memberi dukungan dalam bentuk pertanyaan yang mendorong anak mengembangkan ide, bukan memberi arahan untuk dilakukan anak. Penataan lingkungan yang mendukung belajar adalah lingkungan yang: a. Terjaga kebersihannya; b. Semua alat, perabot, dan kondisi ruangan dipastikan terjaga keamanannya; c. Ditata dengan rapi untuk membiasakan anak berperilaku rapi dan teratur; d. Ditata sesuai dengan tinggi badan anak untuk membangun perilaku mandiri.

9) Berorientasi Pada Pembelajaran Demokratis

Pembelajaran yang demokratis sangat diperlukan untuk mengembangkan rasa saling menghargai antara anak dengan guru, dan dengan anak lain. Pembelajaran demokratis memupuk sikap konsisten pada gagasan sendiri, tetapi menghargai orang lain dan mentaati aturan.

10) Menggunakan Berbagai Media dan Sumber Belajar

Penggunaan media dan sumber yang ada di lingkungan ini bertujuan agar pembelajaran lebih kontekstual dan bermakna, lebih dekat dengan kehidupan anak. Sumber belajar yang dimaksud adalah orang-orang dengan profesi tertentu yang sesuai dengan tema, misalnya: dokter, polisi, nelayan, dan petugas pemadam kebakaran. 


\section{PEMBELAJARAN PENDEKATAN SAINTIFIK}

DENGAN

Pendeketan adalah konsep dasar yang mewadahi, menginspirasi, menguatan, dan melatari pemikiran tentang bagaimana metode pembelajaran diterapkan berdasarkan teori tertentu. Oleh karena itu banyak pandangan yang menyatakan bahwa pendekatan sama artinya dengan metode (Hamruni,2012).

Pendekatan ilmiah berarti konsep dasar yang menginspirasi atau melatarbelakangi perumusan metode mengajar dengan menerapkan karakteristik yang ilmiah. Pendekatan pembelajaran ilmiah (scientific teaching) merupakan bagian dari pendekatan pedagogis pada pelaksanaan pembelajaran dalam kelas yang melandasai penerapan metode ilmiah.

Menurut majalah forum kebijakan ilmiah yang terbit di Amerika pada tahn 2004 sebagimana dikutip Wikipedia menyatakan bahwa pembelajaran ilmiah mencakup strategi pembelajaran peserta didik aktif yang mengintegrasikan peserta didik dalam proses berpikir dan penggunaan metode yang teruji secara ilmiah sehingga dapat membedakan kemampuan peserta didik yang bervariasi. Penerapan metode ilmiah membantu guru mengidentifikasi perbedaan kemampuan peserta didik.

Metode ilmiah merupakan teknik merumuskan pertanyaan dan menjawabnya melalui kegiatan observasi dan melaksanakan percobaan. Dalam penerapan metode ilmiah teradpat aktivitas yang dapat diobservasi seperti mengamati, menanya, mengeksplorasi, mengasosiasi dan mengkomunikasikan (Kemendikbud, 2013).

Jadi pembelajaran dengan pendekatan saintifik adalah proses pembelajaran yang dirancang sedemikian rupa agar peserta didik secara aktif mengkonstruk konsep, hukum atau prinsip melalui tahapan-tahapan mengamati (untuk mengidentifikasi atau menemukan masalah), merumuskan masalah, mengajukan atau merumuskan hipotesis, menumpulkan data dengan berbagai teknik, menganlisis data, menarik kesimpulan dan mengkomunikasikan konsep, hukum atau prinsip yang "ditemukan". Pendekatan saintifik dimaksudkan untuk memberikan pemahaman kepada peserta didik dalam mengenal, memahami berbagai materi menggunakan pendekatan ilmiah, bahwa informasi bisa berasal dari mana saja, kapan saja, tidak bergantung pada informasi searah dari guru. Oleh karena itu kondisi pembelajaran yang diharapkan tercipta diarahkan untuk mendorong peserta didik dalam mencari tahu dari berbagai sumber melalui observasi dan bukan hanya diberi tahu (Kemendikbud, 2013).

\section{MANFAAT PENERAPAN PENDEKATAN SAINTIFIK DI PAUD}

Dalam struktur kurikulum 2013 PAUD hasil belajar anak dituangkan ke dalam kompetensi inti sikap, pengetahuan, dan keterampilan. Proses pembelajaran ditujukan untuk mengembangkan sikap, pengetahuan, dan keterampilan. Penanaman sikap dibangun melalui pembiasaan ( habituasi) dan keteladanan ( modeling). Pengembangan pengetahuan dan keterampilan dilakukan melalui pendekatan saintifik (untuk penanaman sikap akan dipandu dengan pedoman tersendiri (Kemdndikbud. 2015).

Manfaat penerapan pendekatan saintifik, yaitu (Kemendikbud 2015): 1. Lebih mudah diterima oleh anak 2. Lebih bermakna bagi anak 3. Lebih utuh diterima oleh anak 4. Lebih melekat menjadi perilaku anak 5. Mengurangi verbalisme (menghindari guru untuk banyak menjelaskan secara lisan) 6. Lebih mudah diterapkan oleh anak 7. Anak lebih menghargai kemampuan yang diperolehnya 8. Anak lebih percaya diri 9. Anak lebih bangga terhadap kemampuan yang diperolehnya 10. Kemampuan yang diperoleh lebih permanen.

\section{PROSES SAINTIFIK}

a) Mengamati

Mengamati berarti kegiatan menggunakan semua indera (penglihatan, pendengaran, penghiduan, peraba, dan pengecap) untuk mengenali suatu benda yang diamatinya. Semakin banyak indera yang digunakan dalam proses mengamati maka semakin banyak informasi yang diterima dan diproses dalam otak anak. Guru berperan sebagai pengamat dan pendukung/fasilitator bukan sebagai instruktur. Kegiatan mengamati dapat dilakukan bersamasama di dalam atau di luar kelas. Media untuk diamati bisa apapun. Media yang disiapkan sesuai dengan tema yang sedang dipilih. Proses mengamati penting untuk membangun pengetahuan awal anak tentang suatu benda atau kejadian. Guru dapat menuliskan disertai gambar sederhana tentang pengetahuan yang sudah disebutkan anak tadi. Proses mengamati 
juga untuk membangun mninat anak mengetahui lebih banyak tentang sesuatu yang diamatinya.

b) Menanya

Menanya merupakan proses berfikir yang didorong oleh minat keingintahuan anak tentang suatu benda atau kejadian. Pada dasarnya anak senang bertanya. Anak akan terus bertanya sampai rasa penasarannya terjawab. Seringkali orang tua dan guru mematahkan rasa keingintahuan anak dengan menganggap anak yang cerewet.

Menanya sebagai proses menggali pengetahuan baru. Guru dapat membantu anak untuk menyusun pertanyaan yang ingin mereka ketahui. Di tahap menanya, guru perlu bersabar.Terkadang anak menyampaikan keingintahuannya tidak dalam bentuk kalimat tanya.

c) Mengumpulkan Informasi

1) Mengumpulkan informasi/ data merupakan proses mencari jawaban dari pertanyaan-pertanyaan yang disampaikan anak ditahap menanya.

2) Mengumpulkan data dapat dilakukan berulang-ulang di pijakan awal sebelum bermain (pembukaan) setiap hari dengan cara yang berbeda.

3) Mengumpulkan data dapat berasal dari berbagai sumber, baik manusia, buku, film, mengunjungi tempat atau internet.

d) Menalar

Proses menalar untuk anak usia dini menghubungkan atau mencocokkan pengetahuan yang sudah dimilikinya dengan pengalaman baru yang didapatkannya. Sepertinya pernyataan anak-anak di atas tidak nyambung, tetapi sesungguhnya Dafa menghubungkan kangkung termasuk tumbuhan daun dan Alifa menghubungkan binatang yang suka makan daun.

Proses asosiasi dapat terlihat saat anak mampu: a. Menyebutkan persamaan, b. Menyebutkan perbedaan, c. Mengelompokkan, dan d. Membandingkan. e. Mengkomunikasikan Mengomunikasikan adalah proses penguatan pengetahuan / keterampilan baru yang didapatkan anak. Mengomunikasikan dapat dilakukan dengan berbagai cara, misalnya bahasa lisan, gerakan, hasil karya.

Dukungan guru yang tepat akan menguatkan pemahaman anak terhadap konsep atau pengetahuannya, proses berpikir kritis dan kreatifnya terus tumbuh. Sebaliknya bila guru mengabaikan pendapat anak atau menyalahkannya maka keinginan untuk mencari tahu dan mencoba hal baru menjadi hilang (Kemendikbud, 2015).

\section{PENUTUP}

Kurikulum 2013 Pendidikan Anak Usia Dini mengamanatkan bahwa pembelajaran di PAUD menggunakan pendekatan saintifik dalam pemberian rangsangan pendidikan. Adapun langkah-langkah penerapan pendekatan saintifik yang perlu menjadi perhatian kita semua yakni adanya kegiatan mengamati, menanya, mengumpulkan informasi, dan menalar.

Pelaksanaan kegiatan pembelajaran dengan menerapkan pendekatan saintifik tentunya tidak terlepas dari guru memahami prinsip-prinsip pendidikan anak usia dini. Hal ini bertujuan demi terlaksananya kegiatan pendidikan yang sesuai dengan kebutuhan anak. Adapun rekomendasi dari tulisan ini yaitu:

1. Sebagai pendidik, kita perlu mempelajari dengan baik Kurikulum 2013 di PAUD. Dengan demikian, kita dapat menerapkan dengan baik pula.

2. Kita perlu mempelajari serta menerapkan pendekatan saintifik dengan memperhatikan prinsip-prinsip pendidikan anak usia dini.

\section{DAFTAR PUSTAKA}

Daryanto. 2013. Pendekatan Pembelajaran Saintifik Kurikulum. Yogyakarta: Gava Media.

Hamruni. 2012. Strategi Pembelajaran. Yogyakarta: Insan Madani

Helmawati. 2015. Mengenal dan Memahami PAUD. Bandung: PT Remaja Rosdakarya.

Kemendikbud. 2013. Pendekatan dan Strategi Pembelajaran. Jakarta: TP

Kemendikbud. 2013. Pendekatan, Jenis dan Metode Penelitian Pendidikan. Jakarta: TP

Kemendikbud. 2015. Pedoman Pembelajaran Kurikulum Pendidikan Anak Usia Dini. Jakarta: Direktorat Pembinaan Pendidikan AUD Tahun 2015.

Suyadi dan Ulfah. 2012. Konsep Dasar PAUD. Bandung: PT Remaja Rosdakarya. 
Jurnal Smart PAUD, Vol. 2, No. 1, Januari 2019

Maria Fatima Mardina Angkur

Undang-Undang Nomor 20 Tahun 2003 tentang

Sistem Pendidikan Nasional, Pasal 1

Ayat 1. 